Western University

Scholarship@Western

Microbiology \& Immunology Publications

Microbiology \& Immunology Department

3-30-2014

Reciprocity in microbiome and immune system interactions and its implications in disease and health.

Enayat Nikoopour

Bhagirath Singh

Follow this and additional works at: https://ir.lib.uwo.ca/mnipub

Part of the Biochemical Phenomena, Metabolism, and Nutrition Commons, $\underline{\text { Immunology and }}$ Infectious Disease Commons, Medical Immunology Commons, and the Microbiology Commons

Citation of this paper:

Nikoopour, Enayat and Singh, Bhagirath, "Reciprocity in microbiome and immune system interactions and its implications in disease and health." (2014). Microbiology \& Immunology Publications. 39.

https://ir.lib.uwo.ca/mnipub/39 


\title{
Reciprocity in Microbiome and Immune System Interactions and its Implications in Disease and Health
}

\author{
Enayat Nikoopour and Bhagirath Singh ${ }^{*}$ \\ Centre for Human Immunology and Department of Microbiology and Immunology, and Roberts Research Institute, \\ University of Western Ontario, London, Ontario, Canada
}

\begin{abstract}
Adaptation of the whole microbial normal flora residing in a host to its natural habitat over an evolutionary peroid has resulted in peaceful coexistence with mutual benefits for both microbiota and host in steady state. This symbiotic relationship between host and microbiota has a significant impact on shaping the immune response in the host to achieve an immune tolerance to microbiota but retaining the ability to respond to invading pathogens. Perturbation of this balance by manipulation of microbial communities in the host can lead to immune dysregulation and susceptibility to diseases. By studying the host in the absence of microbiota or with alteration of microbiota the complexity of microbial impact on the immune system can be resolved. Conversely, the study of microbiota in the absence of immune system factors can show how the immune system contributes to preservation of the host-microbiota balance. The absence of molecules involved in innate or adaptive immunity in knockout models can perturb the balance between host and microbiota further adding to more immune dysregulation. A better understanding of Microbiome-immune system interaction provides a new opportunity to identity biomarkers and drug targets. This will allow the development of new therapeutic agents for modulating the immune system to improve health with little or no toxicity. The study of interplay between host and microbiota has a promising role in the design of therapeutic interventions for immunopathological diseases arising from imbalanced host and microbiota interactions.
\end{abstract}

Keywords: Adaptive and innate immunity, autoimmunity, helper $\mathrm{T}$ cells, immune regulation, immune system, microbial diversity, microbiome, probiotics.

\begin{abstract}
MICROBIOTA AND IMMUNE SYSTEM DIALOGUE
In an evolutionary process over a long period of interactions between microbial agents and their hosts, microbes adapted themselves to host environment for a peaceful coexistence, mutual benefits, and symbiosis. The whole microbial population residing in a host, especially at mucosal surfaces such as gastrointestinal tract, gut microbiota, could have a big impact on shaping cellular and humoral immunity of the host to accomplish an immune tolerance to commensal bacteria, fulfilling the requirements of biological mutualism. On the other hand. it is olausible that anv change in cellular and humoral immunity can perturb the steady state balance of microbial populations in the gut and in turn, reshape the immune system into a new format. The study of mice, either kept in germ free conditions or being knocked out for specific genes of the immune system, has revealed the intricate complexity of the reciprocal interaction between mammalian host and normal bacterial flora. Specific bacterial phyla have a role in modulating adaptive immune responses and can influence the shift to specific T cell subsets [ $\left.\begin{array}{ll}1 & 5\end{array}\right]$. Conversely, the number of anaerobic commensal bacteria drastically increases in mice deficient for the activation induced cytidine deaminase (AID) gene due to a failure of the humoral immune response in restraining overgrowth of commensal bacteria [6].
\end{abstract}

Address correspondence lo this author at the Department of Microbiology and Immunology, University of Western. Ontario, London, Ontario N6A SCI, Canada; Tel: 1-519-66l-3228; Fax: 1-519-661-3499:

E-mail:bsingh@uwo.ca
Reconstitution of germ free mice with one or a consortium of specific bacteria is a valuable tool to assess the impact of bacteria on immune system development. Colonization of germ free mice with gram negative Bacteroides fragilis [ 7 10] leads to expansion of $1 \mathrm{~L}-10$ producing regulatory $\mathrm{T}$ cells (Tregs), mediated by binding of bacterial capsular polysaccharide antigen (PSA) to TLR2 [9]. Bacteroides fragilis releases PSA in outer membrane vesicles that could be recognized by TLR2 on dendritic cells [11]. Internalization of these vesicles induces tolerogenic IL10 producing dendritic cells that in turn drives the development of IL-10 producing regulatory T cells [1]]. The induction of Tregs by $B$. fragilis is primarily a requirement for efficient colonization of bacteria in a peaceful environment of the gut in a symbiotic host. Furthermore, PSA from B. fragilis is able to suppress antibacterial IL-17 oroduction in the eut lamina propria [8] for further provision of friendly host environment and enhancement of its colonization, Immunoregulatory effects of PSA on immune system are not restricted to the gut and they adjust the balance of Th1/Th2 subsets systemically [7]. Germ free mice show a reduced IFN- $\gamma$ to IL- 4 cytokine ratio compared to conventional mice and colonization of mice with B. fragilis increases IFN- $\gamma$ up to a normal level observed in conventional mice [7]. In an experimental setting, colonization of mice with Bacteroides fragilis leads to protection from colitis development due to PSA-mediated expansion of $\mathrm{IL}-10$ producing regulatory $\mathrm{T}$ cells and suppression of IL-17 producing cells [8]. Capsular polysaccharide A (PSA) of Bacteroides fragilis can also 
protect against central nervous system demyelinating disease, EAE, by induction of IL-10 producing regulatory $\mathrm{T}$ cells $[12,13]$. These immunomodulatory features have also been reported for the other commensal bacterial species [1, 14]. The homing of regulatory $\mathrm{T}$ cells to large intestine is mediated through GPR15 receptor that its expression is modulated by gut microbiota [15]. Conversely, colonization of bacterial species in the gut requires the presence of regulatory $T$ cells and depletion of these cells or perturbation of the Treg to Th17 balance leads to less efficient colonization of Bacteroides fragilis in the gut [10].

\section{INNATE IMMUNE RECEPTORS}

Interaction of bacterial associated molecular patterns with innate immune receptors such as toll like receptors (TLR) or NOD family of intracellular signaling molecules (NLRs) in the gut is proposed as a plausible mechanistic link between microflora and immune system for the induction of tolerogenic response. Direct interaction of polysaccharide A from Bacteroides fragilis with TLR2 on the surface of dendritic cells or regulatory $\mathrm{T}$ cells provides immunologic tolerance for bacterial colonization in the gut mucosa [10, 11]. Bacteroides fragilis lacking PSA are not able to restrain $\mathrm{T}$ helper 17 cell response that is a negative regulator of bacterial colonization [10]. Colonization of germ free mice with a consortium of eight enteric bacterial species, altered Schaedler flora (ASF), expands CD4+CD25+Foxp3+ Tregs in the colon through TLR signaling [14]. Nonetheless, this effect can occur even in the absence of TLRs. A mixture of clostridia species induces IL-10 producing Tregs in the colonic lamina propria of germ free mice that is independent from MyD88 signaling pathway [1]. The effect of MyD88 pathway in microbiota-mediated modulation of immune response has been described by using MyD88 knockout mice [57]. To add another layer to the complexity of microbiomehost interactions, a deficiency in TLR or MyD88 signaling pathway in mice by itself could alter the composition of gut microbiota that secondarily affects immune system. It has been argued that the composition of gut microbiota in TLR or MyD88 deficient mice might not be really different from wild type mice and the apparent observed differences are mainly due to different parental lineage and husbandry rather than genetic difference [16]. Different TLR receptors could have an activating or inhibiting function in one specific setting and blocking of the MyD88 pathway that is common to most of the TLR receptors that have opposing actions could lead to misleading interpretations. Absence of inflammasome signaling pathway molecules in NLR deficient mice leads to disrupted intestinal homeostasis of gut microbiota $[17,18]$.

\section{MATURATION OF CELLULAR IMMUNE RESPONSE}

Colonization of germ free mice with segmented filamentous bacteria (SFB) induces an IL-17 response in the gut lamina propria [5]. The induced Th17 cells are able to protect mice against an intestinal pathogen, Citrobacter rodentium [5], indicating that gut microbiota could empower host defense mechanisms against environmental pathogens or opportunistic pathogens. These Th17 biased cellular changes are not necessarily associated with the gut immunopathology because different subsets of Th17 have been proposed that differ markedly in pathogenic potential $[19,20]$. Adoptive transfer of naturally occurring Th17 cells from the gut does not result in colitis development but rather have a regulatory function [21]. These cells express CTLA-4 and CCR6 while pathogenic Th17 cells produce IL-17, IFN$\gamma$ and TNF- $\alpha$ [21]. The impact of SFB in the gut is not restricted to induction of Th17 cells and the complexity of the overall balance of $\mathrm{T}$ cell responses should be considered for pathogenic or protective clinical outcome. Earlier reports indicated an induction of one specific $\mathrm{T}$ cell subset following colonization of germ free mice with specific bacteria $[1,4]$. For example, germ free mice colonized with clostridial species clusters IV and XIVa promote regulatory $\mathrm{T}$ cell expansion [1, 2] while mice colonized with SFB promote Th17 cells [4]. However, the role of SFB in shaping immune response is much broader than mere induction of one specific subset and it contributes to full maturation of gut immune response [22] and induction of a wide range of $\mathrm{T}$ cell responses comprising of Th17, Th1, Th2 and Treg cells [23]. This might explain why SFB colonization is associated with protection in some experimental models of disease such as the NOD mouse model of type 1 diabetes [24, 25], while it is pathogenic in other experimental settings such as EAE and arthritis [26, 27]. One possible mechanism for a protective role of IL-17 in a mouse colitis model is through modulation of Th1 response [28]. Colitis is more severe in IL-17 deficient mice that are associated with unrestrained Th1 activity [28]. In an arthritis mouse model, segmented filamentous bacteria (SFB) lower the activation threshold for $\mathrm{T}$ cells encountering chronic antigenic exposure in gut draining lymphoid tissues, and thus promote differentiation of pathogenic Th1 cells and enhance the severity of an autoimmune response [3]. In sum, upregulation of both $T$ helper and regulatory $\mathrm{T}$ cell subsets after colonization of germ free mice with $\mathrm{SFB}$ as a prototype of microbiota strongly suggests maturation of the whole cellular immune response rather than preferential expansion of one specific $\mathrm{T}$ cell subset in the gut.

\section{HUMORAL IMMUNE RESPONSE}

In addition to cellular response, $\mathrm{SFB}$ has been reported to induce a strong IgA response [23, 29]. This could prevent overwhelming expansion of SFB or other commnensal bacteria in the gut to preserve intestinal homeostasis. An increased expansion of SFB in the small intestine of $\operatorname{IgA}$ deficient $\mathrm{AID}^{-/-}$mice has been reported [30]. The activationinduced cytidine deaminase (AID) enzyme is required for immunoglobulin class switching and affinity maturation of antibodies in the germinal center of B cell follicles. High affinity IgA is essential for control of commensal species such as SFB and protection against pathogens such as Salmonella typhimurium [31]. Mouse IgA secreting plasma cells produce antimicrobial mediators such as tumor-necrosis factor-alpha (TNF- $\alpha$ ) and inducible nitric oxide synthase (iNOS) in response to microbial stimulation. These cells are absent in germ free mice and colonization of germ free mice with microbiota restores the secretory $\operatorname{IgA}$ response $[6,32]$. Deletion of TNF- $\alpha$ and iNOS in plasma cells leads to reduction in $\operatorname{IgA}$ production, concomitant change in the composition of gut microbiota, and perturbed intestinal 
homeostasis [33]. Point mutation in the AID gene results in hyperplasia of germinal center B cells in gut-associated lymphoid tissues and expansion of microflora in the small intestine [34]. These findings indicate that somatic hypermutation, affinity maturation, and secretory $\operatorname{IgA}$ responses have a critical role in the maintenance of intestinal homeostasis and mucosal defense.

\section{REGULATION OF Th17 RESPONSE}

Gut microbiota could also modulate the number and function of dendritic cells to eschew $\mathrm{T}$ cell response toward a specific $\mathrm{T}$ cell subset. The number of $\mathrm{CX} 3 \mathrm{CR} 1^{+}$dendritic cells is reduced in germ free mice. This subset of dendritic cells preferentially supports $\mathrm{Th} 1$ and $\mathrm{Th} 17 \mathrm{CD}^{+} \mathrm{T}$ cell differentiation [35], in contrast to $\mathrm{CD}_{103^{+}} \mathrm{DCs}$ that preferentially induce differentiation of Foxp $3^{+}$regulatory $\mathrm{T}$ cells [36]. In general, the commensal bacteria in the gut have a significant impact on maturation of the gut immune system [37] and intestinal colonization contributes to combined effector and regulatory $\mathrm{T}$ cell responses. It is interesting that some bacteria such as SFB could depict the overall impact of whole microbiota on immunity in the gut [23]. Microbiotaderived ATP activates purinergic receptors on dendritic cells to induce Th17 cells in lamina propria [38]. The percentage of Th17 cells in gut lamina propria depends on the presence of microbiota, therefore the level of Th17 cells are markedly low in germ free mice [4]. Differences in composition of gut microbiota in mice from different animal facilities contributed to the varied proportions of Th17 cells in lamina propria [4]. The severity of EAE in germ free mice is reduced as a result of lower levels of IL-17 and IFN- $\gamma$ [27]. However colonization of mice with SFB leads to increased infiltration of Th17 cells in the central nervous system and exacerbation of disease [27]. In a mouse model of autoimmune arthritis, germ free mice show attenuation of disease accompanied with lower Th17 cell frequency [26], whereas SFB monocolonization in those mice leads to an increase in Th17 cell numbers in the lamina propria and exacerbation of disease [26]. Contrary to clinical manifestations in EAE and arthritis models [26, 27], the presence of SFB-induced lamina propria resident Th17 cells in NOD mice protect mice from diabetes [24]. This might occur as a result of the regulation of Th17 cells in the small intestine [39]. Migration of Th17 cells to the small intestine through a CCR6/CCL20 chemokine receptor/ligand interaction leads to either deletion of these cells or acquisition of a regulatory IL-10 producing phenotype in the gut [39]. These Th17 cells express the IL-10 receptor and suppress pathogenic Th17 cells in gut via IL-10 signaling [40]. Commensal bacteria can induce expression of IL-25 (IL$17 \mathrm{E}$ ) in intestinal epithelial cells that inhibits production of IL-23, a major survival factor for Th17 cells, to restrain Th17 response [41].

\section{INTESTINAL HOMEOSTASIS AND IMMUNE RESPONSES}

Alteration of gut microbiota with diet, antibiotic treatment, or intestinal pathogens could predispose hosts to immunopathological disorders [42-44]. Interaction of dietary derived natural ligands for aryl hydrocarbon receptor (AhR) helps to maintain intestinal intraepithelial lymphocytes [42].
Disruption of this mechanism as a result of dietary changes compromises the epithelial integrity, increases immune response, and changes composition of gut microflora [42]. Commensal bacteria and their interaction with TLR receptors and MyD88 signaling pathway are required for protection from intestinal epithelial injury in experimental colitis [43]. Elimination of gut normal microflora with antibiotics contributes to high susceptibility of mice to experimental colitis induction with dextran sodium sulfate (DSS) [43]. An entropathogenic bacterium Salmonella enterica inhibits the growth of microbiota in the gut and subsequently predisposes mice to colitis development [44]. Alteration of the gut microbiome by antibiotics in humnas can lead to the development of pathogenic Clostridium difficile infection [45]. In germ free mice, invariant natural killer $\mathrm{T}$ (iNKT) cells in lamina propria contribute to inflammatory bowel disease and asthma. Colonization of germ free mice with conventional microbiota helps to normalize the number and function of iNKT cells and reduce the severity of the immunopathology [46].

\section{MICROBIOME AND IMMUNE SYSTEM BASED DISEASES}

\section{Infectious Diseases}

Microbiota in the gut protect the host from environmental pathogens $[47,48]$ in a process called colonization resistance [49]. Germ-free animals are unable to eradicate Citrobacter rodentium. However, commensals in conventionally raised mice are able to outcompete $C$. rodentium growth [50]. In response to commensal bacteria, paneth cells in the crypts of intestinal epithelial layer produce antibacterial peptides, alpha-defensin or cryptdin, through a TLR dependant pathway [48] to combat invading microorganisms [47, 48]. Intestinal colonizatioin of germ free mice with Bacteroides thetaiotamicron induces expression of antibacterial peptides, RegIII $\beta$ and RegIII $\gamma$ in paneth cells [51]. The antibacterial lectin RegIII $\gamma$ isolates microbiota in the gut from intestinal epithelial surface [52]. This MyD88 pathway dependent production of RegIII $\gamma$ protects the intestinal mucosa against bacterial invasion [53]. Colonization of gut with Bacteroides thetaiotaomicron and B. fragilis suppresses pathogen-mediated colitis [8]. Tryptophan metabolites from Lactobacilli contribute to colonization resistance against Candida species by promoting IL-22 response in innate lymphoid cells in the gut [54].

\section{Allergic Diseases}

In developed countries, changes in human gut microflora as a result of a western style diet or consumption of antibiotics contribute to a higher incidence of atopy and allergic diseases [55]. A significant reduction in intestinal microbial species including Clostridium cluster IV, Faecalibacterium prausnitzii, Akkermansia muciniphila has been reported in atoptic children [56]. In an allergic disease mouse model, intestinal microbiota, particularly during early infancy, play a critical role in regulating immune responses to avoid atopy. In this respect, administration of antibiotics in neonatal mice changes the composition of the bacterial population and exacerbates experimental murine allergic asthma [57]. An inverse relation between Helicobacter pylori presence in human stomach and allergic asthma has 
been proposed [58]. Eradication of Helicobacter pylori by antibiotics abolishes this protective effect [58].

\section{Autoimmune Diseases}

\section{Type 1 Diabetes}

It is well known that there is a sex-based difference in susceptibility to autoimmune diseases with higher female to male incidence rate of disease [59]. Differences in gut microbial composition between two sexes play a major role in this sex bias and contribute to the differential testosterone levels in male and female NOD mice [60,61]. Accordingly, germ free NOD mice lose the sex bias for diabetes incidence and both sexes show a similar rate of disease incidence [61]. Colonization of germ free NOD mice in early life with commensal bacteria increases testosterone levels accompanied by protection from diabetes development [61]. The difference in number and composition of microbiota between male and female mice occurs after puberty. Analysis of microbiota composition before and after adulthood demonstrates that male mice after puberty gradually show variation from initial bacterial flora whereas microbiota from female mice remain stable [61]. These alterations in microbial composition are associated with rise in male hormonal levels and conversely male NOD mice undergoing castration show a bacterial composition similar to female NOD mice [61]. This points to the critical role of male hormones in shaping gut microflora. Transfer of gut microbiota from adult male to young female NOD mice induces elevation of testosterone levels that is beneficial in reducing diabetes incidence [60]. Blocking of androgen receptors in recipient mice abolishes this protective effect [60] that points to the prime role of male hormone signaling in disease prevention. Whereas androgenic hormones protect mice from autoimmunity [62], castration of male mice increases disease susceptibility [63]. The altered microbiota and hormonal differences change the pathogenic potential of $\mathrm{T}$ cells so that adoptive transfer of $\mathrm{T}$ cells from manipulated NOD to NOD/SCID mice is no longer pathogenic in recipient mice [60]. The contribution of microbiota to the sex bias in susceptibility to autoimmune diseases might be beyond mere modulation of hormonal levels [61]. Thus, a two signal model proposed that both microbes and hormones in parallel or in series have a role in the development of autoimmune disease [61]. Hormones can change microbiota composition but not all observed changes in microbiota necessarily lead to change in diabetes incidence [61]. Colonization of germ free mice with gut microbiota increases testosterone levels, but there is no linear relationship between testosterone level and protection from diabetes [61]. The incidence of diabetes development in germ free MyD88-deficient NOD is high [64] and monocolonization of these mice with SFB leads to protection only in male mice that indicates both microbes and sex hormones are critical for protection [61]. In a contrasting report that indicates there is no evidence for the association of germ free status with an increased incidence of diabetes, monoclonization of female NOD mice with an aerobic spore forming bacteria, Bacillus cereus, reduces disease incidence [65]. In sum, sex hormones influence composition of gut microbiota and alternatively, gut microbiota change sex hormone levels.
Nonobese diabetic mice deficient for MyD88 signaling do not develop type 1 diabetes. However, germ free MyD88 ${ }^{-/-}$NOD mice are highly susceptible to diabetes [64]. The composition of gut microbiota in MyD88-deficient NOD mice and wild type NOD mice is remarkably different [64]. It seems that the immune insult on islet cells occurs independently from MyD88 pathway for the interaction of gut microbiota with host cells. The other possibility would be that different TLRs have opposing effects in hostmicrobiota interaction and disruption of the MyD88 signaling pathway that is common for many TLRs masks the potential clinical phenotype. Arguing against these interpretations, the observed differences in microbiota between wild type and TLR or MyD88 deficient mice could be a mere reflection of different parental lineage of mice and not genetic differences [16].

Microbial agents have a role in regulating IFN- $\gamma$ levels [7] that could have a role in protection from type 1 diabetes. Disruption in IFN- $\gamma$ signaling in NOD mice abolishes sex based differences in susceptibility for diabetes development [61]. NOD mice deficient for IFN- $\gamma$ or IFN- $\gamma$ receptor show similar incidence of T1D in both sexes [61]. Of note, the protection observed after immunotherapy with mycobacterial products [66-69] also depends on IFN- $\gamma$ response [68] and administration of recombinant IFN- $\gamma$ inhibits diabetes process in NOD mice [70]. High levels of IFN- $\gamma$ and TNF- $\alpha$ cytokines following adjuvant immunotherapy could have a role in induction of apoptosis in diabetogenic $\mathrm{T}$ cells [67]. The mechanism of adjuvant effect is not restricted to IFN- $\gamma$ regulation and all changes induced upon adjuvant administration might be primarily under influence of mycobacterial adjuvant-induced alterations in compostion of gut microbiota. Adjuvant immunotherapy leads to upregulation of RegII and RegIII genes in islet of NOD mice $[69,71]$. This effect is associated with an increase in IL-22 levels and neutralization of IL-22 abolishes RegII and RegIII gene expression [72]. Mice with IL-22 deficiency demonstrate changes in gut microbiota compostion [73]. Thus, we speculate that mycobacterial adjuvant-induced IL-22 response could go through an intermediary stage for induction of Reg family of antibacterial peptides from intestinal epithelial cells that consequently changes gut microbiota in NOD mice for protection from diabetes development.

Presence of SFB in the gastrointestinal tract of NOD mice is associated with protection from diabetes [24]. While SFB is associated with Th17 cells in NOD mice, no immunopathology is observed in these mice [24]. Th17 cells are not always pathogenic [19,39]. Th17 polarized cells after mycobacterial adjuvant immunotherapy in NOD mice acquire a regulatory phenotype with increased IFN- $\gamma$, IL-17, IL-22 and IL-10 [74]. Th17 cells might not be a main source of pathogenic $\mathrm{T}$ cell as diabetes can happen even in the absence of IL-17A and IL-17F genes in NOD mice [75]. However, the colonic lamina propria of NOD mice show higher levels of Th17 cells and IL-23 mRNA that could be abolished with the use of an anti-diabetogenic diet [76]. In germ-free NOD mice, equal incidence of diabetes, high incidence of insulitis, increased numbers of Th17 and Th1 cells, and diminished numbers of Tregs in mesenteric and pancreatic lymph nodes compared to conventional NOD mice have been reported [77]. In another diabetes model, distinct bacterial populations have been reported in the 
diabetes resistant and diabetes susceptible Bio-Breeding (BB) rats. The protection from diabetes in this animal model is associated with Th17 response in the gut and draining mesenteric lymph nodes. Oral transfer of Lactobacillus johnsonii from diabetes-resistant $\mathrm{BB}$ rats to diabetes -prone $\mathrm{BB}$ rats conferred resistance to diabetes development [78].

\section{Inflammatory Bowel Disease (IBD)}

The human gut environment in a steady state shows a tolerant immune response to microbes residing in the gut. In this respect, an excessive derailed immune response to the gut microbiota might be the main feature of IBD. Intestinal microbiota could be protective against the development of inflammatory diseases and there are reports of alterations in gut microbial communities in patients with IBD [79, 80]. Elimination of gut flora in mice with antibiotics leads to higher susceptibility to experimentally induced colitis [43]. Presence of clostridia clusters IV and XIVa was associated with the presence of regulatory $\mathrm{T}$ cells in the gut lamina propria [1] and maintenance of these bacterial species is necessary for prevention of IBD. Intestinal microbiota convert dietary fiber into short-chain fatty acids (SCFAs) comprised of acetic, propionic, and butyric acids [81]. Interaction of these SCFAs with a $G$ protein-coupled receptor, GPR43, on gut epithelial cells is necessary for dampening inflammatory responses in the gut [81], as mice deficient for GPR43 receptor demonstrate exacerbated intestinal inflammation and colitis. These SCFAs modulate regulatory $\mathrm{T}$ cell responses in terms of number and function in the gut and protect against colitis [82-84]. These three metabolites demonstrate distinct modes of action [82]. Butyrate and propionate exclusively expand regulatory $\mathrm{T}$ cells generated outside the thymus [82]. While acetate just promotes accumulation of regulatory $\mathrm{T}$ cells in colon, butyrate induces de novo generation of regulatory $\mathrm{T}$ cells in the periphery [82]. These metabolites are known as histone deacetylase (HDAC) inhibitors that regulate transcription of Foxp3 gene epigenetically to confer more stability to Foxp3 function in regulatory $\mathrm{T}$ cells $[82,83]$. Regulatory $\mathrm{T}$ cells that are induced in periphery do not express Helios and neurophilin 1, markers of thymic derived Tregs [83]. T cells in the colon express high levels of GPR43 receptor in response to microbiota and receptor engagement contributes to homeostasis of colonic regulatory $\mathrm{T}$ cells and their enhanced suppressive activity for prevention of colitis development [84]. Butyrate also modulates the immune response of macrophages in the gut lamina propria and reduces the production of proinflammatory mediators, IL-6, IL-12 and nitric oxide (NO) [85]. The CX3CR $1{ }^{\text {hi }} \mathrm{CD} 103^{-}$ intestinal macrophages are hyporesponsive to the gut microbiota [85]. In comparison to regulatory $\mathrm{T}$ cells, the anti-inflammatory effect of butyrate on lamina propria macrophages is not mediated by GPR43 receptor but it acts as a histone deacetylase (HDAC) inhibitor [85]. A feature of human ulcerative colitis is a change in normal gut microbiota such as Bifidobacterium and Bacteriodes that lead to reduced production of SCFAs metabolites. Accordingly, germ free mice are not able to produce SCFAs and therefore, are more susceptible to inflammatory responses [81].

Interaction of TLRs with commensal bacteria in the gut helps to maintain intestinal epithelial homeostasis [43]. Disruption of this protective mechanism with the use of broad spectrum antibiotics in mice and consequent changes in the gut microbiota could lead to higher susceptibility to colitis induction in animal models [43]. Deficiency in the inflammasome pathway also leads to increased risk of experimental colitis that is accompanied with changes in commensal microbiota [86, 87]. Deficiency of NLRP6 in mouse colonic epithelial cells results in expansion of the bacterial phyla Bacteroidetes (Prevotellaceae) and TM7 and high susceptibility to experimental colitis that is transferable to normal wild type mice through sharing of gut microbiota [18].

Commensal bacteria such as Bacteroides species could induce disease only in IBD susceptible hosts that are deficient for IL-10 and TGF- $\beta$ cytokines and pre-treated with antibiotics [88]. Antibiotics could be used to reduce the burden of commensal bacteria for the treatment of IBD [89]. Spontaneous colitis in IL-10 deficient mice could be prevented with the disruption of the MyD88 signaling pathway [90], which indicates that IL-10 regulates commensal bacteria driven colitis through the MyD88 pathway. The altered microbiota profile seen in IBD does not necessarily reflect the etiology of the disease and there might be a complex interplay between susceptibility genes and microbiota for disease progression. The extent of colonization of Bacteroides species in both IBD susceptible and non-susceptible stains of mice is the same [88]. Despite preponderance of Enterobacteriaceae in the intestine of the IBD afflicted mice, transfer of these bacteria to IBD susceptible mice does not induce disease [88].

In a TRUC mouse model, RAG deficient mice lacking the T-bet transcription factor, spontaneous colitis devolops that resembles human ulcerative colitis [91]. Gut microbiota in these mice are different from wild type mice and transfer of microbiota to wild type mice results in colitis induction $[91,92]$. T-bet regulates production of TNF- $\alpha$ in dendritic cells to prevent pro-inflammatory response to gut microbiota and thus excessive production of TNF- $\alpha$ by colonic dendritic cells in the TRUC colitis model causes tissue injury in the colon [91].

IL-22 from different cellular sources such as innate lymphoid cells, Th17 cells and natural killer cells can have a protective role in inflammatory bowel disease [73, 93, 94]. IL-22 induces the expression of Reg family of antimicrobial peptides, RegIII $\beta$ and RegIII $\gamma$ in colonic epithelial cells [95]. In the absence of antibacterial effects of IL-22, commensal bacteria can be overwhemingly expanded. IL-22 deficient mice have an altered composition of gut microbiota and demonstrate more severe colitis in an experimental mouse model [73]. Of note, the Lactobacillacae family of normal gut microflora is reduced in these mice [73]. Gut microbiota could be exchanged between co-housed mice because of copraphagia in mice. Transfer of the altered microbiota of IL-22 deficient mice to wild type mice during co-housing leads to colitis development in wild type mice [73]. It is likely that altered flora in turn have a negative feedback on IL-23-IL-22 pathway. In contrast to its role in experimental colitis, IL-22 deficient mice are not susceptible to spontaneous colitis which indicates that IL-22 is not a sole factor for maintaining intestinal homestasis [94]. However, IL-22 from NK cells and $\mathrm{CD}^{+} \mathrm{T}$ cells is protective in experimental colitis induced by DSS or by transfer of 
CD4+CD45RB ${ }^{\text {hi }}$ cells to RAG deficient mice [94]. In a steady state, intestinal IL-22 producing $\mathrm{NKp}^{+} 6^{+}$cells are generated in response to commensal bacteria [96]. A dual protective or pathogenic role for IL-22 in different disease contexts has been reported. The cellular source of IL-22 or accompanying other cytokines in those cells might dictate the protective or pathogenic role of IL-22 in various disease backgrounds.

\section{Multiple Sclerosis and EAE Mouse Model}

Oral administration of antibiotics can modify the composition of gut microbiota to protect mice against experimental autoimmune encephalomyelitis (EAE), an experimental model of multiple sclerosis in humans [97]. This protective effect is associated with a reduced production of inflammatory cytokines, an increased IL-10 producing Foxp $3^{+}$regulatory T cell response [97], and an enhanced IL10 producing regulatory $\mathrm{CD}^{+} \mathrm{B}$ cell response [98]. A probiotic mixture of lactobacilli also induces regulatory $\mathrm{T}$ cells that leads to protection from EAE [99]. Oral treatment with purified PSA antigen derived from human commensal microbiota, Bacteroides fregilis protects mice against EAE by enhancing $\mathrm{CD} 103^{+}$dendritic cells for induction of regulatory $\mathrm{T}$ cells in the gut, mesenteric, and cervical lymphoid nodes $[12,13]$. Similar to a NOD mouse model, administration of mycobacyterial adjuvant has a protective role in an EAE model [100].

\section{Rheumatoid Arthritis}

Analysis of gut microbiota from patients with recentonset rheumatoid arthritis (RA) indicates that there is a strong association of the disease with the presense of Prevotella copri and reduction in Bacteroides and other beneficial gut bacteria [101]. Accordingly, the prevalance of P. copri in patients treated for rheumatoid arthrits is similar to healthy individuals [101]. Mice that are genetically prone to arthritis and colonized with $P$. copri are more susceptible to the experimental induction of colits with DSS [101]. In animal mouse models of arthritis, germ free mice do not develop arthritis but upon colonization with specific gut microbiota demonstrate joint inflammmation [26, 102]. Colonization of germ free mice with segmented filammentous bacteria, SFB, is associated with an elevated Th17 cell response and exacerbation of arthritis [26]. Mice deficient for an IL-1 receptor antagonist (IL-1ra) develop arthritis spontaneously [102]. While these mice in germ free status do not develop arthritis, colonization with a specific gut microbiota, Lactobacillus bifidus results in rapid onset of arthrits [102]. Differential engagement of Toll like receptors by normal microflora impacts the pathogenesis of arthritis in this mouse model. Deficiency for TLR2 in these mice exacerbates the disease, lowers regualtory $\mathrm{T}$ cells and enhances Th1 response, whereas deficiency in TLR4 protects from arthritis and attenuates Th17 response [102]. There might be a connection between the genetic background of host and the compostion of gut microbiota. Analysis of gut microbiome in HLA-DR transgenic mice carrying either the RA susceptible or resistant HLA-DR alleles indicates a differential pattern with the dominance of Clostridium species in RA susceptible transgenic mice [103].

\section{MICROBIOTA AND HEALTH}

The whole bacterial genome from the human gut has been characterized with metagenomic sequencing [104-106]. Analysis of microbiota that could be grown in cultures in vitro indicates that healthy people have similar bacterial species in gut [104]. However, culture independent sequencing shows variations in bacterial species between human populations [104]. Factors such as genetic background, age, diet and consumption of antibiotiotics in host together with environmental agents contribute to variability in the composition of gut microbiota [104]. Monozygotic and dizygotic twins have similar microbiota which indicates that environmental factors are more important in shaping individual variations [104].

\section{Nutrition and Obesity}

Diet can change the composition of gut microbiota to promote obesity. Germ free mice are resistant to obesity that is induced by a western style high fat diet [107]. Transfer of microbiota from mice with diet-induced obesity to germ-free recipient mice promotes fat deposition [108]. Lymphotoxin $\beta$ receptor (LT $\beta R$ ) regulates the microbiota in the gut to induce obesity after intake of high fat diet [109], which indicates that both genetic background of host and composition of microbiota are involved in obesity. A hallmark of dietinduced obesity is the loss of diversity in microbial communities and lower frequency of SFB in the gut [109]. Diet-induced obesity in mice is transferable from susceptible to resistant mice after co-housing of two groups of mice [109]. A High fat diet induces a LT $\beta R$ dependent activation of the IL-23-IL-22 cytokine pathway in innate lymphoid cells to produce IL-22 [109], which is a key player in the process of diet-induced obesity and reduction of SFB colonization [109]. IL-22 driven production of the antibacterial peptide, RegIII $\gamma$, limits the outgrowth of SFB in the gut [109]. Study of fecal microbial communities in twin individuals, being either lean or obese, has shown phylumlevel differences in the gut microbiota [110]. Long-term diet modulates composition of gut microbiome so that diets rich in protein and fat are associated with presence of Bacteroides species whereas diets rich in carbohydrates are associated with Prevotella species [111]. Analysis of gut microbiota in two groups of children from Europe and Africa showed that there is a higher number of Bacteroidetes phylum (Prevotella and Xilanibacter species) and lower number of Firmicutes phylum in African children compared with the European children [112]. The diet of the African children was low in fat and protein and rich in carbohydrate. The presence of specific bacterial communities in these children resulted in more production of short chain fatty acids (SCFA) [112]. Obesity is associated with a decrease in Bacteroidetes phylum and an increase in Firmicutes phylum in the gut [113]. Colonization of germ-free mice with microbiota from genetically leptin-deficient obese mice results in an increase in total body fat in recipient mice $[113,114]$. Microbiota in obese animals are adapted to more efficient energy harvesting and higher absorption of nutrients in the diet [114]. Diets enriched with saturated fat induce dysbiosis in the gut, which leads to a high incidence of colitis in IL-10 deficient mice [115]. Dietary derived natural ligands for aryl hydrocarbon receptor (AhR) help maintain intestinal 
intraepithelial lymphocytes and administration of $\mathrm{AhR}$ ligands promotes expansion of regulatory $T$ cells [116]. Disruption of this pathway due to changes in diet alters the composition of gut microflora and local immune response [42]. In NOD mice, gluten free diet changes microbial communities in the gut and lowers the incidence of diabetes [117]. NOD mice that receive acidified rather than neutral drinking water show an altered compostion of gut microbiota that is associated with more suceptiblity to the development of insulitis and hyperglycemia [118]. Diet in the long run has an influence on the balance of major bacterial phyla by changing the ratio of Bacteroides to Firmicutes in the gut [108].

Comparative analysis of germ free and conventional mice has revealed a profound effect of the gut microbiome on amino acid metabolites [119]. Deficiency in dietary tryptophan changes intestinal microbial composition [120]. Metabolites derived from tryptophan metabolism by indolamine dioxygenase (IDO) are involved in the generation of regulatory $\mathrm{T}$ cells via the aryl hydrocarbon receptor pathway [54]. Tryptophan metabolites from microbiota such as Lactobacilli are also involved in intestinal homeostasis and colonization resistance [54]. These microbiota-derived tryptophan metabolites promote IL-22 responses in innate lymphoid cells in the gut [54]. Tryptophan deficiency leads to dysregulation in the gut immune response, an altered profile of gut microbiota and predisposition to opportunistic infections. The pathway of Tryptophan metabolites-AhR-IL-22 plays a critical role in resistance against colonization by Candida species at mucosal surfaces [54]. IL-22 from innate immune cells can regulate Th17 cell responses. Reduced levels of IL-22 in innate immune cells in AhR deficient mice result in the expansion of SFB in the gut and subsequent expansion of Th17 cells in the intestine leading to colitis development [121].

\section{THERAPEUTIC INTERVENTIONS, PROBIOTICS AND MICROBIOME}

Probiotics are designed to restore gut microbial composition to normal state and adjust the immune system. Suppression of effector response and induction of regulatory $\mathrm{T}$ cells has been reported with the consumption of probiotics [122]. Colonization of mice by Clostridium strains promotes regulatory $\mathrm{T}$ cell response in the gut [1]. Oral administration of Clostridium species during the early life in mice is beneficial in preventing colitis [1]. Consumption of Bifidobacterium infantis in mice leads to an increase in the number of regulatory $\mathrm{T}$ cells and protection against Salmonella typhimurium infection [123]. Bifidobacteria produce acetate that improves intestinal defense against enterohaemorrhagic Escherichia coli [124]. Also, Lactobacillus rhamnosus and Bifidobacterium infantis have a protective effect in the prevention of colitis development [125]. Perturbation of the balance between major bacterial phyla in the gut microbiota, more specifically, a decreased level of a member of Firmicutes, Faecalibacterium prausnitzii, is associated with a higher risk of Crohn's disease [126]. Oral administration of anti-inflammatory commensal $F$. prausnitzii reduces the severity of experimental colitis by correcting the dysbiosis [126]. Fecal microbiota transplantation has shown to be promising in the treatment of Clostridium difficile infections
[127]. Fecal transfer from SFB positive donors suppresses type 1 diabetes in recipient NOD mice [118].

In conclusion, the rapidly growing knowledge of microbiome-host interactions has bought up new avenues in understanding immunopathological basis of disease and gives a promising outlook in conceiving novel therapeutic protocols in health and prevention of diseases.

\section{LIST OF ABBREVIATIONS}

$\begin{array}{ll}\text { AID } & =\text { Activation Induced Cytidine Deaminase } \\ \text { Tregs } & =\text { Regulatory T cells } \\ \text { PSA } & =\text { Polysaccharide Antigen } \\ \text { TLR } & =\text { Toll Like Receptor } \\ \text { NLR } & =\text { Altered Schaedler Flora } \\ \text { ASF } & =\text { Segmented Filamentous Bacteria } \\ \text { SFB } & =\text { Tumor Necrosis Factor alpha } \\ \text { TNF- } \alpha & =\text { Inducible Nitric Oxide Synthase } \\ \text { iNOS } & =\text { Aryl hydrocarbon Receptor } \\ \text { AhR } & \text { iNKT cells } \\ \text { NOD mice } & =\text { Non Obese Diabetic mice } \\ \text { SCID mice } & =\text { Severe Combined Immunodeficiency mice } \\ \text { IBD } & =\text { Inflammatory Bowel Disease } \\ \text { HDAC } & =\text { Histone Deacetylase } \\ \text { DSS } & =\text { Dextran Sulfate Sodium } \\ \text { EAE } & =\text { Experimental Autoimmune Encephalomyelitis } \\ \text { RA } & =\text { Rheumatoid Arthritis } \\ \text { LT } \beta R & \text { Lymphotoxin } \beta \text { Receptor } \\ \text { IDO } & =\text { Indolamine Dioxygenase }\end{array}$

\section{CONFLICT OF INTEREST}

Work in our laboratory is supported by funding from the Canadian Institutes of Health Research and the European Community's Seventh Framework Programme via International Human Microbiome Standards, (HEALTH-F42010-261376) grants. The authors have no finiancial conflict of interest.

\section{ACKNOWLEDGEMENTS}

We thank Kate Simpson-Gallow for editing the manuscript.

\section{REFERENCES}

[1] Atarashi, K.; Tanoue, T.; Shima, T.; Imaoka, A.; Kuwahara, T.; Momose, Y.; Cheng, G.; Yamasaki, S.; Saito, T.; Ohba, Y.; Taniguchi, T.; Takeda, K.; Hori, S.; Ivanov, I. I.; Umesaki, Y.; Itoh, K.; Honda, K. Induction of colonic regulatory $\mathrm{T}$ cells by indigenous Clostridium species. Science, 2011, 331 (6015), 337 341 .

[2] Atarashi, K.; Tanoue, T.; Oshima, K.; Suda, W.; Nagano, Y.; Nishikawa, H.; Fukuda, S.; Saito, T.; Narushima, S.; Hase, K.; 
Kim, S.; Fritz, J. V.; Wilmes, P.; Ueha, S.; Matsushima, K.; Ohno, H.; Olle, B.; Sakaguchi, S.; Taniguchi, T.; Morita, H.; Hattori, M.; Honda, K. Treg induction by a rationally selected mixture of Clostridia strains from the human microbiota. Nature, 2013, 500 (7461), 232-236.

[3] Chappert, P.; Bouladoux, N.; Naik, S.; Schwartz, R. H. Specific gut commensal flora locally alters $\mathrm{T}$ cell tuning to endogenous ligands. Immunity, 2013, 38 (6), 1198-1210.

[4] Ivanov, I. I.; Frutos, R. L.; Manel, N.; Yoshinaga, K.; Rifkin, D. B.; Sartor, R. B.; Finlay, B. B.; Littman, D. R. Specific microbiota direct the differentiation of IL-17-producing T-helper cells in the mucosa of the small intestine. Cell Host. Microbe, 2008, 4 (4), 337349.

[5] Ivanov, I. I.; Atarashi, K.; Manel, N.; Brodie, E. L.; Shima, T.; Karaoz, U.; Wei, D.; Goldfarb, K. C.; Santee, C. A.; Lynch, S. V.; Tanoue, T.; Imaoka, A.; Itoh, K.; Takeda, K.; Umesaki, Y.; Honda, K.; Littman, D. R. Induction of intestinal Th17 cells by segmented filamentous bacteria. Cell, 2009, 139 (3), 485-498.

[6] Fagarasan, S.; Muramatsu, M.; Suzuki, K.; Nagaoka, H.; Hiai, H.; Honjo, T. Critical roles of activation-induced cytidine deaminase in the homeostasis of gut flora. Science, 2002, 298 (5597), 1424-1427.

[7] Mazmanian, S. K.; Liu, C. H.; Tzianabos, A. O.; Kasper, D. L. An immunomodulatory molecule of symbiotic bacteria directs maturation of the host immune system. Cell, 2005, 122 (1), 107118.

[8] Mazmanian, S. K.; Round, J. L.; Kasper, D. L. A microbial symbiosis factor prevents intestinal inflammatory disease. Nature, 2008, 453 (7195), 620-625.

[9] Round, J. L.; Mazmanian, S. K. Inducible Foxp3+ regulatory T-cell development by a commensal bacterium of the intestinal microbiota. Proc. Natl. Acad. Sci. U. S. A, 2010, 107 (27), 1220412209.

[10] Round, J. L.; Lee, S. M.; Li, J.; Tran, G.; Jabri, B.; Chatila, T. A.; Mazmanian, S. K. The Toll-like receptor 2 pathway establishes colonization by a commensal of the human microbiota. Science, 2011, 332 (6032), 974-977.

[11] Shen, Y.; Giardino Torchia, M. L.; Lawson, G. W.; Karp, C. L.; Ashwell, J. D.; Mazmanian, S. K. Outer membrane vesicles of a human commensal mediate immune regulation and disease protection. Cell Host. Microbe, 2012, 12 (4), 509-520.

[12] Ochoa-Reparaz, J.; Mielcarz, D. W.; Wang, Y.; Begum-Haque, S.; Dasgupta, S.; Kasper, D. L.; Kasper, L. H. A polysaccharide from the human commensal Bacteroides fragilis protects against CNS demyelinating disease. Mucosal. Immunol., 2010, 3 (5), 487-495.

[13] Ochoa-Reparaz, J.; Mielcarz, D. W.; Ditrio, L. E.; Burroughs, A. R.; Begum-Haque, S.; Dasgupta, S.; Kasper, D. L.; Kasper, L. H. Central nervous system demyelinating disease protection by the human commensal Bacteroides fragilis depends on polysaccharide A expression. J. Immunol., 2010, 185 (7), 4101-4108.

[14] Geuking, M. B.; Cahenzli, J.; Lawson, M. A.; Ng, D. C.; Slack, E.; Hapfelmeier, S.; McCoy, K. D.; Macpherson, A. J. Intestinal bacterial colonization induces mutualistic regulatory $\mathrm{T}$ cell responses. Immunity., 2011, 34 (5), 794-806.

[15] Kim, S. V.; Xiang, W. V.; Kwak, C.; Yang, Y.; Lin, X. W.; Ota, M.; Sarpel, U.; Rifkin, D. B.; Xu, R.; Littman, D. R. GPR15mediated homing controls immune homeostasis in the large intestine mucosa. Science, 2013, 340 (6139), 1456-1459.

[16] Ubeda, C.; Lipuma, L.; Gobourne, A.; Viale, A.; Leiner, I.; Equinda, M.; Khanin, R.; Pamer, E. G. Familial transmission rather than defective innate immunity shapes the distinct intestinal microbiota of TLR-deficient mice. J. Exp. Med., 2012, 209 (8), 1445-1456.

[17] Bouskra, D.; Brezillon, C.; Berard, M.; Werts, C.; Varona, R.; Boneca, I. G.; Eberl, G. Lymphoid tissue genesis induced by commensals through NOD1 regulates intestinal homeostasis. Nature, 2008, 456 (7221), 507-510.

[18] Elinav, E.; Strowig, T.; Kau, A. L.; Henao-Mejia, J.; Thaiss, C. A.; Booth, C. J.; Peaper, D. R.; Bertin, J.; Eisenbarth, S. C.; Gordon, J. I.; Flavell, R. A. NLRP6 inflammasome regulates colonic microbial ecology and risk for colitis. Cell, 2011, 145 (5), 745-757.

[19] Ghoreschi, K.; Laurence, A.; Yang, X. P.; Tato, C. M.; McGeachy, M. J.; Konkel, J. E.; Ramos, H. L.; Wei, L.; Davidson, T. S.; Bouladoux, N.; Grainger, J. R.; Chen, Q.; Kanno, Y.; Watford, W. T.; Sun, H. W.; Eberl, G.; Shevach, E. M.; Belkaid, Y.; Cua, D. J.; Chen, W.; O'Shea, J. J. Generation of pathogenic T(H)17 cells in the absence of TGF-beta signalling. Nature, 2010, 467 (7318), 967971.

[20] Singh, B.; Schwartz, J. A.; Sandrock, C.; Bellemore, S. M.; Nikoopour, E. Modulation of autoimmune diseases by interleukin (IL)-17 producing regulatory T helper (Th17) cells. Indian J. Med. Res., 2013, 138 (5), 591-594.

[21] Ono, Y.; Kanai, T.; Sujino, T.; Nemoto, Y.; Kanai, Y.; Mikami, Y.; Hayashi, A.; Matsumoto, A.; Takaishi, H.; Ogata, H.; Matsuoka, K.; Hisamatsu, T.; Watanabe, M.; Hibi, T. T-helper 17 and interleukin-17-producing lymphoid tissue inducer-like cells make different contributions to colitis in mice. Gastroenterology, 2012, 143 (5), 1288-1297.

[22] Chung, H.; Pamp, S. J.; Hill, J. A.; Surana, N. K.; Edelman, S. M.; Troy, E. B.; Reading, N. C.; Villablanca, E. J.; Wang, S.; Mora, J. R.; Umesaki, Y.; Mathis, D.; Benoist, C.; Relman, D. A.; Kasper, D. L. Gut immune maturation depends on colonization with a hostspecific microbiota. Cell, 2012, 149 (7), 1578-1593.

[23] Gaboriau-Routhiau, V.; Rakotobe, S.; Lecuyer, E.; Mulder, I.; Lan, A.; Bridonneau, C.; Rochet, V.; Pisi, A.; De, P. M.; Brandi, G.; Eberl, G.; Snel, J.; Kelly, D.; Cerf-Bensussan, N. The key role of segmented filamentous bacteria in the coordinated maturation of gut helper T cell responses. Immunity, 2009, 31 (4), 677-689.

[24] Kriegel, M. A.; Sefik, E.; Hill, J. A.; Wu, H. J.; Benoist, C.; Mathis, D. Naturally transmitted segmented filamentous bacteria segregate with diabetes protection in nonobese diabetic mice. Proc. Natl. Acad. Sci. U. S. A, 2011, 108 (28), 11548-11553.

[25] Summers, K. L.; Singh, B. Research highlights: highlights from the latest articles in immunotherapy. Immunotherapy, 2012, 4 (4), 363364.

[26] Wu, H. J.; Ivanov, I. I.; Darce, J.; Hattori, K.; Shima, T.; Umesaki, Y.; Littman, D. R.; Benoist, C.; Mathis, D. Gut-residing segmented filamentous bacteria drive autoimmune arthritis via $\mathrm{T}$ helper 17 cells. Immunity, 2010, 32 (6), 815-827.

[27] Lee, Y. K.; Menezes, J. S.; Umesaki, Y.; Mazmanian, S. K. Proinflammatory T-cell responses to gut microbiota promote experimental autoimmune encephalomyelitis. Proc. Natl. Acad. Sci. U. S. A, 2011, 108 (Suppl 1) 4615-4622.

[28] O'Connor, W., Jr.; Kamanaka, M.; Booth, C. J.; Town, T.; Nakae, S.; Iwakura, Y.; Kolls, J. K.; Flavell, R. A. A protective function for interleukin 17A in T cell-mediated intestinal inflammation. Nat. Immunol., 2009, 10 (6), 603-609.

[29] Talham, G. L.; Jiang, H. Q.; Bos, N. A.; Cebra, J. J. Segmented filamentous bacteria are potent stimuli of a physiologically normal state of the murine gut mucosal immune system. Infect. Immun. 1999, 67 (4), 1992-2000.

[30] Suzuki, K.; Meek, B.; Doi, Y.; Muramatsu, M.; Chiba, T.; Honjo, T.; Fagarasan, S. Aberrant expansion of segmented filamentous bacteria in IgA-deficient gut. Proc. Natl. Acad. Sci. U. S. A, 2004, 101 (7), 1981-1986.

[31] Slack, E.; Balmer, M. L.; Fritz, J. H.; Hapfelmeier, S. Functional flexibility of intestinal IgA - broadening the fine line. Front Immunol., 2012, 3, 100.

[32] Macpherson, A. J.; Uhr, T. Induction of protective IgA by intestinal dendritic cells carrying commensal bacteria. Science, 2004, 303 (5664), 1662-1665.

[33] Fritz, J. H.; Rojas, O. L.; Simard, N.; McCarthy, D. D.; Hapfelmeier, S.; Rubino, S.; Robertson, S. J.; Larijani, M.; Gosselin, J.; Ivanov, I. I.; Martin, A.; Casellas, R.; Philpott, D. J.; Girardin, S. E.; McCoy, K. D.; Macpherson, A. J.; Paige, C. J.; Gommerman, J. L. Acquisition of a multifunctional IgA+ plasma cell phenotype in the gut. Nature, 2012, 481 (7380), 199-203.

[34] Wei, M.; Shinkura, R.; Doi, Y.; Maruya, M.; Fagarasan, S.; Honjo, $\mathrm{T}$. Mice carrying a knock-in mutation of Aicda resulting in a defect in somatic hypermutation have impaired gut homeostasis and compromised mucosal defense. Nat. Immunol., 2011, 12 (3), 264270.

[35] Niess, J. H.; Adler, G. Enteric flora expands gut lamina propria CX3CR1+ dendritic cells supporting inflammatory immune responses under normal and inflammatory conditions. J. Immunol., 2010, 184 (4), 2026-2037.

[36] Coombes, J. L.; Siddiqui, K. R.; rancibia-Carcamo, C. V.; Hall, J.; Sun, C. M.; Belkaid, Y.; Powrie, F. A functionally specialized population of mucosal CD103+ DCs induces Foxp3+ regulatory T cells via a TGF-beta and retinoic acid-dependent mechanism. $J$. Exp. Med., 2007, 204 (8), 1757-1764. 
[37] Artis, D. Epithelial-cell recognition of commensal bacteria and maintenance of immune homeostasis in the gut. Nat. Rev. Immunol., 2008, 8 (6), 411-420.

[38] Atarashi, K.; Nishimura, J.; Shima, T.; Umesaki, Y.; Yamamoto, M.; Onoue, M.; Yagita, H.; Ishii, N.; Evans, R.; Honda, K.; Takeda, K. ATP drives lamina propria $\mathrm{T}(\mathrm{H}) 17$ cell differentiation. Nature, 2008, 455 (7214), 808-812.

[39] Esplugues, E.; Huber, S.; Gagliani, N.; Hauser, A. E.; Town, T.; Wan, Y. Y.; O'Connor, W., Jr.; Rongvaux, A.; Van, R. N.; Haberman, A. M.; Iwakura, Y.; Kuchroo, V. K.; Kolls, J. K.; Bluestone, J. A.; Herold, K. C.; Flavell, R. A. Control of TH17 cells occurs in the small intestine. Nature, 2011, 475 (7357), 514518.

[40] Huber, S.; Gagliani, N.; Esplugues, E.; O'Connor, W., Jr.; Huber, F. J.; Chaudhry, A.; Kamanaka, M.; Kobayashi, Y.; Booth, C. J.; Rudensky, A. Y.; Roncarolo, M. G.; Battaglia, M.; Flavell, R. A. Th17 cells express interleukin-10 receptor and are controlled by Foxp3(-) and Foxp3+ regulatory CD4+ T cells in an interleukin-10dependent manner. Immunity, 2011, 34 (4), 554-565.

[41] Zaph, C.; Du, Y.; Saenz, S. A.; Nair, M. G.; Perrigoue, J. G.; Taylor, B. C.; Troy, A. E.; Kobuley, D. E.; Kastelein, R. A.; Cua, D. J.; Yu, Y.; Artis, D. Commensal-dependent expression of IL-25 regulates the IL-23-IL-17 axis in the intestine. J. Exp. Med., 2008, $205(10), 2191-2198$.

[42] Li, Y.; Innocentin, S.; Withers, D. R.; Roberts, N. A.; Gallagher, A. R.; Grigorieva, E. F.; Wilhelm, C.; Veldhoen, M. Exogenous stimuli maintain intraepithelial lymphocytes via aryl hydrocarbon receptor activation. Cell, 2011, 147 (3), 629-640.

[43] Rakoff-Nahoum, S.; Paglino, J.; Eslami-Varzaneh, F.; Edberg, S.; Medzhitov, R. Recognition of commensal microflora by toll-like receptors is required for intestinal homeostasis. Cell, 2004, 118 (2), 229-241.

[44] Stecher, B.; Robbiani, R.; Walker, A. W.; Westendorf, A. M.; Barthel, M.; Kremer, M.; Chaffron, S.; Macpherson, A. J.; Buer, J.; Parkhill, J.; Dougan, G.; von, M. C.; Hardt, W. D. Salmonella enterica serovar typhimurium exploits inflammation to compete with the intestinal microbiota. PLoS. Biol., 2007, 5 (10), 21772189.

[45] de La Cochetiere, M. F.; Durand, T.; Lalande, V.; Petit, J. C.; Potel, G.; Beaugerie, L. Effect of antibiotic therapy on human fecal microbiota and the relation to the development of Clostridium difficile. Microb. Ecol., 2008, 56 (3), 395-402.

[46] Olszak, T.; An, D.; Zeissig, S.; Vera, M. P.; Richter, J.; Franke, A.; Glickman, J. N.; Siebert, R.; Baron, R. M.; Kasper, D. L.; Blumberg, R. S. Microbial exposure during early life has persistent effects on natural killer T cell function. Science, 2012, 336 (6080), 489-493.

[47] Ayabe, T.; Satchell, D. P.; Wilson, C. L.; Parks, W. C.; Selsted, M. E.; Ouellette, A. J. Secretion of microbicidal alpha-defensins by intestinal Paneth cells in response to bacteria. Nat. Immunol., 2000, $1(2), 113-118$.

[48] Vaishnava, S.; Behrendt, C. L.; Ismail, A. S.; Eckmann, L.; Hooper, L. V. Paneth cells directly sense gut commensals and maintain homeostasis at the intestinal host-microbial interface. Proc. Natl. Acad. Sci. U. S. A, 2008, 105 (52), 20858-20863.

[49] Buffie, C. G.; Pamer, E. G. Microbiota-mediated colonization resistance against intestinal pathogens. Nat. Rev. Immunol., 2013, 13 (11), 790-801.

[50] Kamada, N.; Kim, Y. G.; Sham, H. P.; Vallance, B. A.; Puente, J. L.; Martens, E. C.; Nunez, G. Regulated virulence controls the ability of a pathogen to compete with the gut microbiota. Science, 2012, 336 (6086), 1325-1329.

[51] Cash, H. L.; Whitham, C. V.; Behrendt, C. L.; Hooper, L. V. Symbiotic bacteria direct expression of an intestinal bactericidal lectin. Science, 2006, 313 (5790), 1126-1130.

[52] Vaishnava, S.; Yamamoto, M.; Severson, K. M.; Ruhn, K. A.; Yu, X.; Koren, O.; Ley, R.; Wakeland, E. K.; Hooper, L. V. The antibacterial lectin RegIIIgamma promotes the spatial segregation of microbiota and host in the intestine. Science, 2011, 334 (6053), 255-258.

[53] Brandl, K.; Plitas, G.; Schnabl, B.; DeMatteo, R. P.; Pamer, E. G. MyD88-mediated signals induce the bactericidal lectin RegIII gamma and protect mice against intestinal Listeria monocytogenes infection. J. Exp. Med., 2007, 204 (8), 1891-1900.

[54] Zelante, T.; Iannitti, R. G.; Cunha, C.; De, L. A.; Giovannini, G.; Pieraccini, G.; Zecchi, R.; D'Angelo, C.; Massi-Benedetti, C.;
Fallarino, F.; Carvalho, A.; Puccetti, P.; Romani, L. Tryptophan catabolites from microbiota engage aryl hydrocarbon receptor and balance mucosal reactivity via interleukin-22. Immunity, 2013, 39 (2), 372-385.

[55] Shreiner, A.; Huffnagle, G. B.; Noverr, M. C. The "Microflora Hypothesis" of allergic disease. Adv. Exp. Med. Biol., 2008, 635 113-134.

[56] Candela, M.; Rampelli, S.; Turroni, S.; Severgnini, M.; Consolandi, C.; De, B. G.; Masetti, R.; Ricci, G.; Pession, A.; Brigidi, P. Unbalance of intestinal microbiota in atopic children. BMC. Microbiol., 2012, 1295

[57] Russell, S. L.; Gold, M. J.; Hartmann, M.; Willing, B. P.; Thorson, L.; Wlodarska, M.; Gill, N.; Blanchet, M. R.; Mohn, W. W.; McNagny, K. M.; Finlay, B. B. Early life antibiotic-driven changes in microbiota enhance susceptibility to allergic asthma. EMBO Rep., 2012, 13 (5), 440-447.

[58] Arnold, I. C.; Dehzad, N.; Reuter, S.; Martin, H.; Becher, B.; Taube, C.; Muller, A. Helicobacter pylori infection prevents allergic asthma in mouse models through the induction of regulatory T cells. J. Clin. Invest., 2011, 121 (8), 3088-3093.

[59] Whitacre, C. C. Sex differences in autoimmune disease. Nat. Immunol., 2001, 2 (9), 777-780.

[60] Markle, J. G.; Frank, D. N.; Mortin-Toth, S.; Robertson, C. E.; Feazel, L. M.; Rolle-Kampczyk, U.; von, B. M.; McCoy, K. D.; Macpherson, A. J.; Danska, J. S. Sex differences in the gut microbiome drive hormone-dependent regulation of autoimmunity. Science, 2013, 339 (6123), 1084-1088.

[61] Yurkovetskiy, L.; Burrows, M.; Khan, A. A.; Graham, L.; Volchkov, P.; Becker, L.; Antonopoulos, D.; Umesaki, Y.; Chervonsky, A. V. Gender bias in autoimmunity is influenced by microbiota. Immunity, 2013, 39 (2), 400-412.

[62] Fox, H. S. Androgen treatment prevents diabetes in nonobese diabetic mice. J. Exp. Med., 1992, 175 (5), 1409-1412.

[63] Makino, S.; Kunimoto, K.; Muraoka, Y.; Katagiri, K. Effect of castration on the appearance of diabetes in NOD mouse. Jikken Dobutsu, 1981, 30 (2), 137-140.

[64] Wen, L.; Ley, R. E.; Volchkov, P. Y.; Stranges, P. B.; Avanesyan, L.; Stonebraker, A. C.; Hu, C.; Wong, F. S.; Szot, G. L.; Bluestone, J. A.; Gordon, J. I.; Chervonsky, A. V. Innate immunity and intestinal microbiota in the development of Type 1 diabetes. Nature, 2008, 455 (7216), 1109-1113.

[65] King, C.; Sarvetnick, N. The incidence of type-1 diabetes in NOD mice is modulated by restricted flora not germ-free conditions. PLoS One, 2011, 6 (2), e17049

[66] Qin, H. Y.; Sadelain, M. W.; Hitchon, C.; Lauzon, J.; Singh, B. Complete Freund's adjuvant-induced $\mathrm{T}$ cells prevent the development and adoptive transfer of diabetes in nonobese diabetic mice. J. Immunol., 1993, 150 (5), 2072-2080.

[67] Qin, H. Y.; Chaturvedi, P.; Singh, B. In vivo apoptosis of diabetogenic $\mathrm{T}$ cells in NOD mice by IFN-gamma/TNF-alpha. Int. Immunol., 2004, 16 (12), 1723-1732.

[68] Serreze, D. V.; Chapman, H. D.; Post, C. M.; Johnson, E. A.; Suarez-Pinzon, W. L.; Rabinovitch, A. Th1 to Th2 cytokine shifts in nonobese diabetic mice: sometimes an outcome, rather than the cause, of diabetes resistance elicited by immunostimulation. $J$. Immunol., 2001, 166 (2), 1352-1359.

[69] Singh, B.; Nikoopour, E.; Huszarik, K.; Elliott, J. F.; Jevnikar, A M. Immunomodulation and regeneration of islet Beta cells by cytokines in autoimmune type 1 diabetes. J. Interferon Cytokine Res., 2011, 31 (10), 711-719.

[70] Sobel, D. O.; Han, J.; Williams, J.; Yoon, J. W.; Jun, H. S.; Ahvazi, B. Gamma interferon paradoxically inhibits the development of diabetes in the NOD mouse. J. Autoimmun., 2002, 19 (3), 129-137.

[71] Huszarik, K.; Wright, B.; Keller, C.; Nikoopour, E.; Krougly, O.; Lee-Chan, E.; Qin, H. Y.; Cameron, M. J.; Gurr, W. K.; Hill, D. J.; Sherwin, R. S.; Kelvin, D. J.; Singh, B. Adjuvant immunotherapy increases beta cell regenerative factor Reg2 in the pancreas of diabetic mice. J. Immunol., 2010, 185 (9), 5120-5129.

[72] Hill, T.; Krougly, O.; Nikoopour, E.; Bellmore, S.; Lee-Chan, E.; Fouser, L. A.; Hill, D. J.; Singh, B. The involvement of interleukin22 in the expression of pancreatic beta cell regenerative Reg genes. Cell Regeneration, 2013, 2 (2), 1-11.

[73] Zenewicz, L. A.; Yin, X.; Wang, G.; Elinav, E.; Hao, L.; Zhao, L.; Flavell, R. A. IL-22 deficiency alters colonic microbiota to be transmissible and colitogenic. J. Immunol., 2013, 190 (10), 53065312. 
[74] Nikoopour, E.; Schwartz, J. A.; Huszarik, K.; Sandrock, C.; Krougly, O.; Lee-Chan, E.; Singh, B. Th17 polarized cells from nonobese diabetic mice following mycobacterial adjuvant immunotherapy delay type 1 diabetes. J. Immunol., 2010, 184 (9), 4779-4788.

[75] Joseph, J.; Bittner, S.; Kaiser, F. M.; Wiendl, H.; Kissler, S. IL-17 silencing does not protect nonobese diabetic mice from autoimmune diabetes. J. Immunol., 2012, 188 (1), 216-221.

[76] Alam, C.; Valkonen, S.; Palagani, V.; Jalava, J.; Eerola, E.; Hanninen, A. Inflammatory tendencies and overproduction of IL17 in the colon of young NOD mice are counteracted with diet change. Diabetes, 2010, 59 (9), 2237-2246.

[77] Alam, C.; Bittoun, E.; Bhagwat, D.; Valkonen, S.; Saari, A.; Jaakkola, U.; Eerola, E.; Huovinen, P.; Hanninen, A. Effects of a germ-free environment on gut immune regulation and diabetes progression in non-obese diabetic (NOD) mice. Diabetologia, 2011, 54 (6), 1398-1406.

[78] Lau, K.; Benitez, P.; Ardissone, A.; Wilson, T. D.; Collins, E. L.; Lorca, G.; Li, N.; Sankar, D.; Wasserfall, C.; Neu, J.; Atkinson, M. A.; Shatz, D.; Triplett, E. W.; Larkin, J., III Inhibition of type 1 diabetes correlated to a Lactobacillus johnsonii N6.2-mediated Th17 bias. J. Immunol., 2011, 186 (6), 3538-3546.

[79] Frank, D. N.; St Amand, A. L.; Feldman, R. A.; Boedeker, E. C.; Harpaz, N.; Pace, N. R. Molecular-phylogenetic characterization of microbial community imbalances in human inflammatory bowel diseases. Proc. Natl. Acad. Sci. U. S. A, 2007, 104 (34), 1378013785.

[80] Frank, D. N.; Robertson, C. E.; Hamm, C. M.; Kpadeh, Z.; Zhang, T.; Chen, H.; Zhu, W.; Sartor, R. B.; Boedeker, E. C.; Harpaz, N.; Pace, N. R.; Li, E. Disease phenotype and genotype are associated with shifts in intestinal-associated microbiota in inflammatory bowel diseases. Inflamm. Bowel. Dis., 2011, 17 (1), 179-184.

[81] Maslowski, K. M.; Vieira, A. T.; Ng, A.; Kranich, J.; Sierro, F.; Yu, D.; Schilter, H. C.; Rolph, M. S.; Mackay, F.; Artis, D.; Xavier, R. J.; Teixeira, M. M.; Mackay, C. R. Regulation of inflammatory responses by gut microbiota and chemoattractant receptor GPR43. Nature, 2009, 461 (7268), 1282-1286.

[82] Arpaia, N.; Campbell, C.; Fan, X.; Dikiy, S.; van, d., V; deRoos, P.; Liu, H.; Cross, J. R.; Pfeffer, K.; Coffer, P. J.; Rudensky, A. Y. Metabolites produced by commensal bacteria promote peripheral regulatory T-cell generation. Nature, 2013, 504 (7480), 451-455.

[83] Furusawa, Y.; Obata, Y.; Fukuda, S.; Endo, T. A.; Nakato, G.; Takahashi, D.; Nakanishi, Y.; Uetake, C.; Kato, K.; Kato, T.; Takahashi, M.; Fukuda, N. N.; Murakami, S.; Miyauchi, E.; Hino, S.; Atarashi, K.; Onawa, S.; Fujimura, Y.; Lockett, T.; Clarke, J. M.; Topping, D. L.; Tomita, M.; Hori, S.; Ohara, O.; Morita, T.; Koseki, H.; Kikuchi, J.; Honda, K.; Hase, K.; Ohno, H. Commensal microbe-derived butyrate induces the differentiation of colonic regulatory T cells. Nature, 2013, 504 (7480), 446-450.

[84] Smith, P. M.; Howitt, M. R.; Panikov, N.; Michaud, M.; Gallini, C. A.; Bohlooly, Y.; Glickman, J. N.; Garrett, W. S. The microbial metabolites, short-chain fatty acids, regulate colonic Treg cell homeostasis. Science, 2013, 341 (6145), 569-573.

[85] Chang, P. V.; Hao, L.; Offermanns, S.; Medzhitov, R. The microbial metabolite butyrate regulates intestinal macrophage function via histone deacetylase inhibition. Proc. Natl. Acad. Sci. U. S. A, 2014, 111(6), 2247-52.

[86] Zaki, M. H.; Boyd, K. L.; Vogel, P.; Kastan, M. B.; Lamkanfi, M.; Kanneganti, T. D. The NLRP3 inflammasome protects against loss of epithelial integrity and mortality during experimental colitis. Immunity, 2010, 32 (3), 379-391.

[87] Hirota, S. A.; Ng, J.; Lueng, A.; Khajah, M.; Parhar, K.; Li, Y.; Lam, V.; Potentier, M. S.; Ng, K.; Bawa, M.; McCafferty, D. M.; Rioux, K. P.; Ghosh, S.; Xavier, R. J.; Colgan, S. P.; Tschopp, J.; Muruve, D.; Macdonald, J. A.; Beck, P. L. NLRP3 inflammasome plays a key role in the regulation of intestinal homeostasis. Inflamm. Bowel. Dis., 2011, 17 (6), 1359-1372.

[88] Bloom, S. M.; Bijanki, V. N.; Nava, G. M.; Sun, L.; Malvin, N. P.; Donermeyer, D. L.; Dunne, W. M., Jr.; Allen, P. M.; Stappenbeck, T. S. Commensal Bacteroides species induce colitis in hostgenotype-specific fashion in a mouse model of inflammatory bowel disease. Cell Host. Microbe, 2011, 9 (5), 390-403.

[89] Ohkusa, T.; Kato, K.; Terao, S.; Chiba, T.; Mabe, K.; Murakami, K.; Mizokami, Y.; Sugiyama, T.; Yanaka, A.; Takeuchi, Y.; Yamato, S.; Yokoyama, T.; Okayasu, I.; Watanabe, S.; Tajiri, H.; Sato, N. Newly developed antibiotic combination therapy for ulcerative colitis: a double-blind placebo-controlled multicenter trial. Am. J. Gastroenterol., 2010, 105 (8), 1820-1829.

[90] Rakoff-Nahoum, S.; Hao, L.; Medzhitov, R. Role of toll-like receptors in spontaneous commensal-dependent colitis. Immunity., 2006, 25 (2), 319-329.

[91] Garrett, W. S.; Lord, G. M.; Punit, S.; Lugo-Villarino, G.; Mazmanian, S. K.; Ito, S.; Glickman, J. N.; Glimcher, L. H. Communicable ulcerative colitis induced by T-bet deficiency in the innate immune system. Cell, 2007, 131 (1), 33-45.

[92] Garrett, W. S.; Gallini, C. A.; Yatsunenko, T.; Michaud, M.; DuBois, A.; Delaney, M. L.; Punit, S.; Karlsson, M.; Bry, L.; Glickman, J. N.; Gordon, J. I.; Onderdonk, A. B.; Glimcher, L. H. Enterobacteriaceae act in concert with the gut microbiota to induce spontaneous and maternally transmitted colitis. Cell Host Microbe, 2010, 8 (3), 292-300.

[93] Sugimoto, K.; Ogawa, A.; Mizoguchi, E.; Shimomura, Y.; Andoh, A.; Bhan, A. K.; Blumberg, R. S.; Xavier, R. J.; Mizoguchi, A. IL22 ameliorates intestinal inflammation in a mouse model of ulcerative colitis. J. Clin. Invest., 2008, 118 (2), 534-544.

[94] Zenewicz, L. A.; Yancopoulos, G. D.; Valenzuela, D. M.; Murphy, A. J.; Stevens, S.; Flavell, R. A. Innate and adaptive interleukin-22 protects mice from inflammatory bowel disease. Immunity, 2008, 29 (6), 947-957.

[95] Zheng, Y.; Valdez, P. A.; Danilenko, D. M.; Hu, Y.; Sa, S. M.; Gong, Q.; Abbas, A. R.; Modrusan, Z.; Ghilardi, N.; de Sauvage, F. J.; Ouyang, W. Interleukin-22 mediates early host defense against attaching and effacing bacterial pathogens. Nat. Med., 2008, 14 (3), 282-289.

[96] Satoh-Takayama, N.; Vosshenrich, C. A.; Lesjean-Pottier, S.; Sawa, S.; Lochner, M.; Rattis, F.; Mention, J. J.; Thiam, K.; CerfBensussan, N.; Mandelboim, O.; Eberl, G.; Di Santo, J. P. Microbial flora drives interleukin 22 production in intestinal NKp46+ cells that provide innate mucosal immune defense. Immunity, 2008, 29 (6), 958-970.

[97] Ochoa-Reparaz, J.; Mielcarz, D. W.; Ditrio, L. E.; Burroughs, A. R.; Foureau, D. M.; Haque-Begum, S.; Kasper, L. H. Role of gut commensal microflora in the development of experimental autoimmune encephalomyelitis. J. Immunol., 2009, 183 (10), 60416050.

[98] Ochoa-Reparaz, J.; Mielcarz, D. W.; Haque-Begum, S.; Kasper, L. $\mathrm{H}$. Induction of a regulatory $\mathrm{B}$ cell population in experimental allergic encephalomyelitis by alteration of the gut commensal microflora. Gut Microbes., 2010, 1 (2), 103-108.

[99] Lavasani, S.; Dzhambazov, B.; Nouri, M.; Fak, F.; Buske, S.; Molin, G.; Thorlacius, H.; Alenfall, J.; Jeppsson, B.; Westrom, B. A novel probiotic mixture exerts a therapeutic effect on experimental autoimmune encephalomyelitis mediated by IL-10 producing regulatory T cells. PLoS One, 2010, 5 (2), e9009

[100] Lee, J.; Reinke, E. K.; Zozulya, A. L.; Sandor, M.; Fabry, Z. Mycobacterium bovis bacille Calmette-Guerin infection in the CNS suppresses experimental autoimmune encephalomyelitis and Th17 responses in an IFN-gamma-independent manner. J. Immunol., 2008, 181 (9), 6201-6212.

[101] Scher, J. U.; Sczesnak, A.; Longman, R. S.; Segata, N.; Ubeda, C.; Bielski, C.; Rostron, T.; Cerundolo, V.; Pamer, E. G.; Abramson, S. B.; Huttenhower, C.; Littman, D. R. Expansion of intestinal Prevotella copri correlates with enhanced susceptibility to arthritis. Elife., 2013, 2 e01202

[102] Abdollahi-Roodsaz, S.; Joosten, L. A.; Koenders, M. I.; Devesa, I.; Roelofs, M. F.; Radstake, T. R.; Heuvelmans-Jacobs, M.; Akira, S.; Nicklin, M. J.; Ribeiro-Dias, F.; van den Berg, W. B. Stimulation of TLR2 and TLR4 differentially skews the balance of T cells in a mouse model of arthritis. J. Clin. Invest., 2008, 118 (1), 205-216.

[103] Gomez, A.; Luckey, D.; Yeoman, C. J.; Marietta, E. V.; Berg Miller, M. E.; Murray, J. A.; White, B. A.; Taneja, V. Loss of sex and age driven differences in the gut microbiome characterize arthritis-susceptible 0401 mice but not arthritis-resistant 0402 mice. PLoS One, 2012, 7 (4), e 36095

[104] Lozupone, C. A.; Stombaugh, J. I.; Gordon, J. I.; Jansson, J. K.; Knight, R. Diversity, stability and resilience of the human gut microbiota. Nature, 2012, 489 (7415), 220-230.

[105] Qin, J.; Li, R.; Raes, J.; Arumugam, M.; Burgdorf, K. S.; Manichanh, C.; Nielsen, T.; Pons, N.; Levenez, F.; Yamada, T.; Mende, D. R.; Li, J.; Xu, J.; Li, S.; Li, D.; Cao, J.; Wang, B.; Liang, H.; Zheng, H.; Xie, Y.; Tap, J.; Lepage, P.; Bertalan, M.; Batto, J. M.; Hansen, T.; Le, P. D.; Linneberg, A.; Nielsen, H. B.; 
Pelletier, E.; Renault, P.; Sicheritz-Ponten, T.; Turner, K.; Zhu, H.; Yu, C.; Li, S.; Jian, M.; Zhou, Y.; Li, Y.; Zhang, X.; Li, S.; Qin, N.; Yang, H.; Wang, J.; Brunak, S.; Dore, J.; Guarner, F.; Kristiansen, K.; Pedersen, O.; Parkhill, J.; Weissenbach, J.; Bork, P.; Ehrlich, S. D.; Wang, J. A human gut microbial gene catalogue established by metagenomic sequencing. Nature, 2010, 464 (7285), 59-65.

[106] Yatsunenko, T.; Rey, F. E.; Manary, M. J.; Trehan, I.; DominguezBello, M. G.; Contreras, M.; Magris, M.; Hidalgo, G.; Baldassano, R. N.; Anokhin, A. P.; Heath, A. C.; Warner, B.; Reeder, J.; Kuczynski, J.; Caporaso, J. G.; Lozupone, C. A.; Lauber, C.; Clemente, J. C.; Knights, D.; Knight, R.; Gordon, J. I. Human gut microbiome viewed across age and geography. Nature, 2012, 486 (7402), 222-227.

[107] Backhed, F.; Manchester, J. K.; Semenkovich, C. F.; Gordon, J. I. Mechanisms underlying the resistance to diet-induced obesity in germ-free mice. Proc. Natl. Acad. Sci. U. S. A, 2007, 104 (3), 979984.

[108] Turnbaugh, P. J.; Backhed, F.; Fulton, L.; Gordon, J. I. Dietinduced obesity is linked to marked but reversible alterations in the mouse distal gut microbiome. Cell Host Microbe, 2008, 3 (4), 213223.

[109] Upadhyay, V.; Poroyko, V.; Kim, T. J.; Devkota, S.; Fu, S.; Liu, D.; Tumanov, A. V.; Koroleva, E. P.; Deng, L.; Nagler, C.; Chang, E. B.; Tang, H.; Fu, Y. X. Lymphotoxin regulates commensal responses to enable diet-induced obesity. Nat. Immunol., 2012, 13 (10), 947-953.

[110] Turnbaugh, P. J.; Hamady, M.; Yatsunenko, T.; Cantarel, B. L.; Duncan, A.; Ley, R. E.; Sogin, M. L.; Jones, W. J.; Roe, B. A.; Affourtit, J. P.; Egholm, M.; Henrissat, B.; Heath, A. C.; Knight, R.; Gordon, J. I. A core gut microbiome in obese and lean twins. Nature, 2009, 457 (7228), 480-484.

[111] Wu, G. D.; Chen, J.; Hoffmann, C.; Bittinger, K.; Chen, Y. Y.; Keilbaugh, S. A.; Bewtra, M.; Knights, D.; Walters, W. A.; Knight, R.; Sinha, R.; Gilroy, E.; Gupta, K.; Baldassano, R.; Nessel, L.; Li, H.; Bushman, F. D.; Lewis, J. D. Linking long-term dietary patterns with gut microbial enterotypes. Science, 2011, 334 (6052), 105-108.

[112] de, F. C.; Cavalieri, D.; Di, P. M.; Ramazzotti, M.; Poullet, J. B.; Massart, S.; Collini, S.; Pieraccini, G.; Lionetti, P. Impact of diet in shaping gut microbiota revealed by a comparative study in children from Europe and rural Africa. Proc. Natl. Acad. Sci. U. S. A, 2010, 107 (33), 14691-14696.

[113] Ley, R. E.; Turnbaugh, P. J.; Klein, S.; Gordon, J. I. Microbial ecology: human gut microbes associated with obesity. Nature, 2006, 444 (7122), 1022-1023.

[114] Turnbaugh, P. J.; Ley, R. E.; Mahowald, M. A.; Magrini, V.; Mardis, E. R.; Gordon, J. I. An obesity-associated gut microbiome with increased capacity for energy harvest. Nature, 2006, 444 (7122), 1027-1031.

[115] Devkota, S.; Wang, Y.; Musch, M. W.; Leone, V.; Fehlner-Peach, H.; Nadimpalli, A.; Antonopoulos, D. A.; Jabri, B.; Chang, E. B. Dietary-fat-induced taurocholic acid promotes pathobiont expansion and colitis in Il10-/- mice. Nature, 2012, 487 (7405), 104-108.

[116] Quintana, F. J.; Murugaiyan, G.; Farez, M. F.; Mitsdoerffer, M.; Tukpah, A. M.; Burns, E. J.; Weiner, H. L. An endogenous aryl hydrocarbon receptor ligand acts on dendritic cells and $\mathrm{T}$ cells to suppress experimental autoimmune encephalomyelitis. Proc. Natl. Acad. Sci. U. S. A, 2010, 107 (48), 20768-20773.

[117] Marietta, E. V.; Gomez, A. M.; Yeoman, C.; Tilahun, A. Y.; Clark, C. R.; Luckey, D. H.; Murray, J. A.; White, B. A.; Kudva, Y. C.; Rajagopalan, G. Low incidence of spontaneous type 1 diabetes in non-obese diabetic mice raised on gluten-free diets is associated with changes in the intestinal microbiome. PLoS One, 2013, 8 (11), e78687

[118] Sofi, M. H.; Gudi, R. R.; Karumuthil-Melethil, S.; Perez, N.; Johnson, B. M.; Vasu, C. pH of drinking water influences the composition of gut microbiome and type 1 diabetes incidence. Diabetes, 2014, 63(2), 632-44.

[119] Wikoff, W. R.; Anfora, A. T.; Liu, J.; Schultz, P. G.; Lesley, S. A.; Peters, E. C.; Siuzdak, G. Metabolomics analysis reveals large effects of gut microflora on mammalian blood metabolites. Proc. Natl. Acad. Sci. U. S. A, 2009, 106 (10), 3698-3703.

[120] Hashimoto, T.; Perlot, T.; Rehman, A.; Trichereau, J.; Ishiguro, H.; Paolino, M.; Sigl, V.; Hanada, T.; Hanada, R.; Lipinski, S.; Wild, B.; Camargo, S. M.; Singer, D.; Richter, A.; Kuba, K.; Fukamizu, A.; Schreiber, S.; Clevers, H.; Verrey, F.; Rosenstiel, P.; Penninger, J. M. ACE2 links amino acid malnutrition to microbial ecology and intestinal inflammation. Nature, 2012, 487 (7408), 477-481.

[121] Qiu, J.; Guo, X.; Chen, Z. M.; He, L.; Sonnenberg, G. F.; Artis, D. Fu, Y. X.; Zhou, L. Group 3 innate lymphoid cells inhibit T-cellmediated intestinal inflammation through aryl hydrocarbon receptor signaling and regulation of microflora. Immunity, 2013, 39 (2), 386-399.

[122] Kwon, H. K.; Lee, C. G.; So, J. S.; Chae, C. S.; Hwang, J. S.; Sahoo, A.; Nam, J. H.; Rhee, J. H.; Hwang, K. C.; Im, S. H. Generation of regulatory dendritic cells and CD4+Foxp3+ T cells by probiotics administration suppresses immune disorders. Proc Natl. Acad. Sci. U. S. A, 2010, 107 (5), 2159-2164.

[123] O'Mahony, C.; Scully, P.; O'Mahony, D.; Murphy, S.; O'Brien, F.; Lyons, A.; Sherlock, G.; MacSharry, J.; Kiely, B.; Shanahan, F.; O'Mahony, L. Commensal-induced regulatory $\mathrm{T}$ cells mediate protection against pathogen-stimulated NF-kappaB activation. PLoS. Pathog., 2008, 4 (8), e1000112

[124] Fukuda, S.; Toh, H.; Hase, K.; Oshima, K.; Nakanishi, Y.; Yoshimura, K.; Tobe, T.; Clarke, J. M.; Topping, D. L.; Suzuki, T.; Taylor, T. D.; Itoh, K.; Kikuchi, J.; Morita, H.; Hattori, M.; Ohno, H. Bifidobacteria can protect from enteropathogenic infection through production of acetate. Nature, 2011, 469 (7331), 543-547.

[125] van der, K. H.; O'Mahony, C.; Shanahan, F.; O'Mahony, L.; Bienenstock, J. Protective effects of Lactobacillus rhamnosus [corrected] and Bifidobacterium infantis in murine models for colitis do not involve the vagus nerve. Am. J. Physiol. Regul. Integr. Comp. Physiol., 2008, 295 (4), R1131-R1137-R1137.

[126] Sokol, H.; Pigneur, B.; Watterlot, L.; Lakhdari, O.; BermudezHumaran, L. G.; Gratadoux, J. J.; Blugeon, S.; Bridonneau, C.; Furet, J. P.; Corthier, G.; Grangette, C.; Vasquez, N.; Pochart, P.; Trugnan, G.; Thomas, G.; Blottiere, H. M.; Dore, J.; Marteau, P.; Seksik, P.; Langella, P. Faecalibacterium prausnitzii is an antiinflammatory commensal bacterium identified by gut microbiota analysis of Crohn disease patients. Proc. Natl. Acad. Sci. U. S. A, 2008, 105 (43), 16731-16736.

[127] Kelly, C. R.; Kunde, S. S.; Khoruts, A. Guidance on preparing an investigational new drug application for fecal microbiota transplantation studies. Clin. Gastroenterol. Hepatol., 2014, 12(2), 283-8. 